\title{
Scaling up gender mainstreaming in transport: policies, practices and monitoring processes
}

\section{Peter Njenga MA}

Executive Director, International Forum for Rural Transport,

Pretoria, South Africa (corresponding author: peter.njenga@ifrtd.org)
Nite Tanzarn MSC

Independent Consultant, Kampala, Uganda

Four rural transport programmes, one each in Ghana, Uganda, Kenya and Tanzania, were reviewed in respect of gender mainstreaming. National gender frameworks and transport policies were analysed for each country. The four countries have constitutional, policy and legislative frameworks that underpin the principles of gender equality. Gender mainstreaming measures have further been cascaded downwards into sector policies, including transport. The programmes reviewed showed good practices in integration of gender across the project cycle. However, it is notable that the programmes reviewed were donor-funded and thus were significantly influenced by the gender policies of the funding mechanisms. While it was not ascertained if government-funded rural transport programmes had similarly embedded gender integration issues, there is undoubtedly a good foundation that has been laid through the programmes reviewed in this study. This practice needs to be replicated and institutionalised so that it becomes a common norm across all transport programmes. An important part of this is for national governments to ensure sector-wide enforcement of the constitutional and legislative gender precepts. The case study programmes reviewed have put in place some good gender performance assessment tools, which provide examples of the tools that could be made mandatory as part of gender accountability in the transport sector.

\section{Introduction}

This study was based on four small case studies of gender mainstreaming in rural transport, carried out in Ghana, Uganda, Kenya and Tanzania (Ghana and Uganda provided the backbone of the research work, combining a literature review with key informant interviews; Kenya and Tanzania provided supplementary case studies based on a literature review and desk study). The paper takes forward an emerging debate on ways to institutionalise gender mainstreaming in transport policies and practice. The case studies were carried out by the International Forum for Rural Transport and Development on behalf of the Research for Community Access Partnership, which is funded by the UK's Department for International Development (DFID).

The case studies were based on the following rural transport programmes.

(a) Ghana - Second Transport Rehabilitation Project (TRPII: 1991-1997), funded by the World Bank.

(b) Kenya - Roads 2000 Programme, central phases 1 and 2 (Roads 2000/AFD 1\&2: 2007-2011, 2013-2017), funded by the Kenyan and French governments.

(c) Tanzania - Village Travel and Transport Programme (VTTP: 1995-2004) and one of its off-shoots, the Local Government Transport Programme (LGTP: 2008-present).

(d) Uganda - Danish International Development Agency (Danida)-funded Road Sector Programme Support phases 1 and 2 (RSPS1 and RSPS2: 1999-2002, 2003-2007) and the Rural Roads Programme (RRP: 2008-2010)

\subsection{Methodology}

The case studies employed qualitative methods of data collection. These consisted of desk studies in all the four countries and key informant interviews in Ghana and Uganda where more detailed work was carried out. The key informant interviews used open-ended questionnaires to elicit information on successes, challenges, perceptions and lessons learnt. These interviews targeted ministries of transport, development partners, civil society organisations and the private sector. The desk studies involved a review of national policy documents to map out the national gender policy landscape. Project documents from the case study programmes were reviewed to assess the tools, indicators and targets used to mainstream gender at different stages of the project cycle, namely identification, design, appraisal, implementation, monitoring and evaluation.

\subsection{Structure of the paper}

This remainder of the paper is structured as follows. Section 2 provides a short overview of relevant literature. Section 3 profiles the national gender policy frameworks in the four countries and section 4 provides gender indicators in the four countries. Section 5 narrows down to the specific case study transport programmes. It provides an assessment of the extent to which gender sensitivity analysis was embedded in respective stages of the programmes (namely, identification, design and appraisal, budgeting, implementation, monitoring and evaluation). Section 6 provides a synthesis of the lessons learnt based on key informant interviews and analysis of the documents reviewed. Section 7 presents the conclusions to the paper. 


\section{Brief literature review}

The World Economic Forum (WEF, 2017) reports that a variety of models and empirical studies show that improving gender parity may result in significant economic dividends. Transport is a key enabler of development and livelihoods and will enable progress in many areas covered by sustainable development goals. In the context of developing countries, these include health, quality education, food security and clean water (Njenga, 2016). These services are particularly central to the livelihoods and well-being of women.

The opportunities to access, use and benefit from rural transport systems differ between men and women. Women in particular are more constrained in accessing and affording means of transport and are more sensitive to issues of predictability, reliability, security and safety of transport services. In addition, how transport infrastructure is prioritised and the usage patterns that develop often lead to a divergence of opportunities that become available for women and men (Njenga and Tanzarn, 2018).

Most of the early work on gender and transport emphasised African women's time poverty and how this is exacerbated by transport-related labour demands. Pioneering research in Ghana (Howe and Barwell, 1987) and Tanzania (Barwell and Malmberg Calvo, 1989; Dawson and Barwell, 1993) underscored the unequal transport burden between rural women and men. A common thread was the role of culture and patriarchy in framing the gender roles related to transport. For example, Cresswell and Uteng (2008) observed that narratives of mobility and immobility play a central role in the constitution of gender as a social and cultural construct. Lack of access to transport is another recurring theme. Studies indicate that while women are the main transporters, there are gender differences in the ownership and use of means of transport due to a variety of cultural and economic reasons (Bryceson and Howe, 1993; Curtis, 1986; Doran, 1990; Malmberg Calvo, 1994; Mudzamba and ILO, 1998; Starkey, 2001; Urasa, 1990).

Much of the development sector has made considerable strides towards gender equality, but transport retains the traditional characteristics of male dominance (Tanzarn, 2017). The gender inequalities that have been entrenched in the sector are embodied in the perceived male capabilities that are required to enter into road construction as engineers or project managers, contractors or operators of transport services and other auxiliary transport enterprises. Apart from barriers that are placed on women's entry into the transport sector businesses, there are also cultural insinuations and underlying security risks that undermine the ability of women to enjoy transport freely.

Emerging work is now highlighting the need for a more comprehensive understanding of the barriers that women face in making full use of transport systems. Table 1 provides
Table 1. Aspects of transport and impacts on women (adapted from Tanzarn (2017))

\begin{tabular}{|c|c|}
\hline Transport issue & Examples of concerns for women \\
\hline $\begin{array}{l}\text { Non-motorised } \\
\text { transport }\end{array}$ & $\begin{array}{l}\text { Affordability } \\
\text { Cultural inhibitions in use } \\
\text { Inappropriate technical features }\end{array}$ \\
\hline $\begin{array}{l}\text { Public transport } \\
\text { services }\end{array}$ & $\begin{array}{l}\text { Fear of verbal and physical } \\
\text { harassment } \\
\text { Vulnerability when transport schedule } \\
\text { is unreliable } \\
\text { Affordability }\end{array}$ \\
\hline $\begin{array}{l}\text { Road infrastructure } \\
\text { construction }\end{array}$ & $\begin{array}{l}\text { Under-representation in employment } \\
\text { opportunities due to disparities in } \\
\text { skills } \\
\text { Where labour-based methods (LBMs) } \\
\text { are used to increase employment, } \\
\text { women are disadvantaged in } \\
\text { balancing the required labour } \\
\text { intensity with domestic } \\
\text { responsibilities } \\
\text { Where infrastructure development } \\
\text { leads to land acquisition, women } \\
\text { tend to be marginalised in } \\
\text { compensation and resettlement } \\
\text { decisions } \\
\text { Influx of male migrant workers into } \\
\text { construction camps may disrupt } \\
\text { communities, more so women and } \\
\text { young girls }\end{array}$ \\
\hline
\end{tabular}

examples of how different aspects of rural transport impact differently on women compared with men.

The structural nature of the problem of gender mainstreaming in transport requires deployment of a more integrated set of interventions through policy, planning and budgeting to ensure that gender integration issues in transport are embedded and institutionalised until they become common and widespread practices. This institutionalisation process would help overcome the observation that gender mainstreaming efforts in transport are primarily donor-driven (Porter, 2012; Starkey, 2001; Tanzarn, 2016).

The underlying premise of this project was that rural transport interventions that give consideration to gender differences may result in significant and more equitable benefits to women and men in terms of increased access to socio-economic services. This is besides the potential to address women's time poverty as well as promote safe transport and travel environments for women.

\section{Gender profiles in the case study countries}

With the exception of Ghana, the case study countries are predominantly rural. Poor mobility is particularly apparent for a significant proportion of rural women and men in all the case study countries. 
The national constitutions of all the four case study countries provide progressive provisions on gender equality, empowerment and the upholding of women's rights. The constitution of Ghana (RoG, 1992) outlaws gender-based discrimination and commits the state to ensuring the full integration of women into the mainstream of economic development. The national Constitution of Kenya, 2010 (RoK, 2010) requires the state to enact affirmative action programmes to ensure that marginalised groups, including women, are provided special opportunities in education and employment and have reasonable access to water, health services and infrastructure. Tanzania's Constitution of 1977, revised in 2004 (URT, 2004), obligates the state and all its agencies to direct their policies and programmes to accord equal opportunities to all citizens, women and men alike. It also provides for affirmative action for women's representation in political leadership. In Uganda, the 1995 Constitution, amended in 2005 (GoU, 2005), recognises equality between women and men, provides for gender balance and fair representation, recognises the role of women in society, accords affirmative action in favour of women and articulates the specific rights of women including outlawing customs, traditions and practices that undermine their welfare and interests.

A review of the legislative and policy environments in the four case study countries showed that they have reasonably enabling policy frameworks for gender mainstreaming. Legislation in areas such as labour laws promotes equal opportunities in employment, recognises women's maternity role and generally provides for a gender-sensitive working environment. The overarching long- and medium-term policy frameworks for the four countries (Kenya's Vision 2030 (RoK, 2007) and Medium-Term Plan 2 (RoK, 2013), Tanzania's Second National Five-Year Development (URT, 2016), Uganda's Vision 2040 (GoU, 2007) and Ghana's Vision 2020 (RoG, 1995)) contain genderequality-enhancing strategies that are supposed to be translated into periodic sector-specific plans and legislation.

Table 2 summarises the national gender policy directives in the four countries within the context of the roads sub-sector.

\section{Gender equality indicators}

Table 3 provides a summary of a range of gender equality indicators in the case study countries.

\subsection{Gender-based discrimination}

The Organisation for Economic Cooperation and Development has developed an instrument known as the social institutions and gender index, which is a composite tool that measures gender-based discrimination in social norms, attitudes and practices that impose restrictions on women's and girls' access to rights, justice and empowerment opportunities. According to the index (OECD, 2014), women in Kenya and Uganda experience medium levels of discrimination, while high levels of discrimination are recorded in Ghana and Tanzania.
The types of discrimination recorded under the OECD's social institutions and gender index translate into the widening of gender gaps in development outcomes such as poverty, education, skills, employment and incomes.

\subsection{Human development}

The United Nations Development Programme (UNDP) categorises Ghana among the countries with medium human development, ranking 139 out of 188 (UNDP, 2016). At a rank of 146 , Kenya is regarded as one of the rapidly developing countries. On the other hand, Tanzania is categorised among the poorest countries in the world, ranking 159. Uganda has the lowest level of human development among the case study countries, with a rank of 163 . Women in Uganda are particularly vulnerable to poverty with more femaleheaded households $(62 \cdot 8 \%)$ than male-headed households $(50 \cdot 5 \%)$ experiencing multi-dimensional aspects of deprivation (UBOS, 2014).

\subsection{Gender inequalities}

Based on various statistical sources, Table 3 provides an overview of key gender equality indicators for the case study countries. The UNDP uses the gender development index (GDI) as a component of the human development index (HDI). To calculate the GDI, the HDI is calculated separately for females and males using the same methodology as in the HDI. According to UNDP, Tanzania is categorised under group 3, which comprises countries with medium equality in human development achievements between women and men (UNDP, 2016). Kenya is categorised under group 4, which comprises countries with medium to low equality in HDI achievements between women and men. Ghana and Uganda are categorised under group 5 - countries with the lowest equality in HDI achievements between women and men.

With regard to the gender inequality index (GII), which benchmarks national gender gaps based on economic, political, education and health criteria, Uganda ranks 121 out of 159 countries assessed (UNDP, 2016), largely due to the progress registered regarding women's political participation. Tanzania, Ghana and Kenya rank 129, 131 and 135 on the GII, respectively.

With a ranking of 45 out of 144 countries assessed, Uganda outperforms the rest of the case study (and other African) countries as regards the global gender gap index (GGGI), which seeks to capture the magnitude of national gender-based disparities. Tanzania, Ghana and Kenya rank 68, 72 and 76 on the GGGI, respectively (WEF, 2017).

Ghana is one of the high performers in respect of closing the gender gaps in labour force participation, wage equality and income, ranking 14 out of the 144 countries assessed on the GGGI: economic participation and opportunity (WEF, 2017). All the four case study countries fare poorly with regard to 


\begin{tabular}{|c|c|c|c|c|c|c|c|c|c|}
\hline \multirow{3}{*}{$\begin{array}{l}\text { Policy directive } \\
\text { Mainstream gender in transport policy/address women's } \\
\text { transport needs }\end{array}$} & \multicolumn{8}{|c|}{ Legislation/policy/instrument } & \multirow{3}{*}{$\begin{array}{l}\text { Targeted sector } \\
\text { instrument }\end{array}$} \\
\hline & \multicolumn{2}{|c|}{ Ghana } & \multicolumn{2}{|c|}{ Kenya } & \multicolumn{2}{|c|}{ Tanzania } & \multicolumn{2}{|c|}{ Uganda } & \\
\hline & & $\begin{array}{l}\text { NDPF } \\
\text { NGP }\end{array}$ & - & $\begin{array}{l}\text { Vision } 2030 \\
\text { (RoK, 2007) } \\
\text { MTP2 }\end{array}$ & घ & $\begin{array}{l}\text { Constitution } \\
\text { (URT, 2004) } \\
\text { Vision 2025 } \\
\text { (URT, 2000) }\end{array}$ & - & $\begin{array}{l}\text { Vision } 2040 \\
\text { (GoU, 2007) } \\
\text { NDPII }\end{array}$ & \\
\hline Adopt labour-based methods (LBMs) & - & & - & & - & & - & NDPII & Transport policy and \\
\hline Provide improved access to reproductive health care & - & & घ & Vision 2030 & - & & घ & Vision 2030 & strategic investment plans \\
\hline Provide improved access to schools & - & & [ & Vision 2030 & - & & ש & Vision 2030 & \\
\hline $\begin{array}{l}\text { Promote female entrepreneurship in contracting and transport } \\
\text { operations through skills development and the provision of } \\
\text { incentives }\end{array}$ & घ & NDPF & $\mathbf{\square}$ & Performance Contract & घ & FYDP ॥ & $\mathbf{\square}$ & NDPII & \\
\hline $\begin{array}{l}\text { Allocate resources to remove barriers to women's participation } \\
\text { in the transport sector, relative to men's }\end{array}$ & 口 & NDPF & $\mathbf{\square}$ & $\begin{array}{l}\text { Public Procurement } \\
\text { and Asset Disposal } \\
\text { Act (RoK, 2015) } \\
\text { Performance Contract }\end{array}$ & - & & घ & PFMA & $\begin{array}{l}\text { Transport policy and } \\
\text { strategic investment plans }\end{array}$ \\
\hline $\begin{array}{l}\text { Allocate resources to enhance women's benefit from transport } \\
\text { infrastructure and operations, relative to men's }\end{array}$ & - & NDPF & - & & - & & - & & \\
\hline $\begin{array}{l}\text { Mainstream gender in transport planning, budgeting and road } \\
\text { improvement }\end{array}$ & 口 & $\begin{array}{l}\text { NDPF } \\
\text { NGP }\end{array}$ & - & & - & Constitution & & $\begin{array}{l}\text { PFMA } \\
\text { Vision } 2040 \\
\text { NDPII }\end{array}$ & $\begin{array}{l}\text { Roads sub-sector } \\
\text { institutions }\end{array}$ \\
\hline Provide/promote appropriate transport technologies for women & - & & 口 & Constitution & a & Constitution & [ & NDPII & Transport regulations \\
\hline $\begin{array}{l}\text { Transport legislation and regulations should be sensitive to } \\
\text { women's needs }\end{array}$ & a & $\begin{array}{l}\text { Constitution } \\
\text { NDPF } \\
\text { NGP }\end{array}$ & - & $\begin{array}{l}\text { Constitution } \\
\text { MTP2 }\end{array}$ & 口 & $\begin{array}{l}\text { Constitution } \\
\text { Vision } 2025\end{array}$ & $\square$ & $\begin{array}{l}\text { Constitution } \\
\text { NDPII }\end{array}$ & $\begin{array}{l}\text { Transport legislation and } \\
\text { regulations }\end{array}$ \\
\hline Address retrogressive cultural practices in construction projects & $\mathbf{\square}$ & NDPF & - & & - & & & $\begin{array}{l}\text { Constitution } \\
\text { Vision } 2040 \\
\text { NDPI }\end{array}$ & $\begin{array}{l}\text { Transport policy, investment } \\
\text { plans, guidelines }\end{array}$ \\
\hline $\begin{array}{l}\text { Address sexual and gender-based violence (SGBV) in } \\
\text { construction projects }\end{array}$ & $\mathbf{\square}$ & NDPF & 口 & $\begin{array}{l}\text { Vision } 2030 \\
\text { MTP2 }\end{array}$ & - & FYDP ॥ & & $\begin{array}{l}\text { Constitution } \\
\text { Vision } 2040 \\
\text { NDPII }\end{array}$ & $\begin{array}{l}\text { Transport policy } \\
\text { Technical specifications } \\
\text { Contract documents }\end{array}$ \\
\hline Provide women-friendly transport services, spaces and facilities & 口 & $\begin{array}{l}\text { Constitution } \\
\text { NGP }\end{array}$ & - & $\begin{array}{l}\text { Vision } 2030 \\
\text { MTP2 }\end{array}$ & - & Constitution & घ & $\begin{array}{l}\text { Constitution } \\
\text { Vision } 2040\end{array}$ & Transport regulations \\
\hline Address SGBV in public transportation & घ & NDPF & 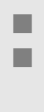 & $\begin{array}{l}\text { Vision } 2030 \\
\text { MTP2 }\end{array}$ & 口 & FYDP II & & $\begin{array}{l}\text { Constitution } \\
\text { Vision } 2040 \\
\text { NDPII }\end{array}$ & Transport regulations \\
\hline $\begin{array}{l}\text { Ensure women's and girls' autonomous mobility and safety in } \\
\text { public transport spaces }\end{array}$ & 口 & $\begin{array}{l}\text { NDPF } \\
\text { NGP }\end{array}$ & a & $\begin{array}{l}\text { Vision } 2030 \\
\text { MTP2 }\end{array}$ & - & & & $\begin{array}{l}\text { Constitution } \\
\text { Vision } 2040 \\
\text { NDPII }\end{array}$ & Transport regulations \\
\hline $\begin{array}{l}\text { Gender balance in the governance of roads sub-sector } \\
\text { institutions }\end{array}$ & 口 & $\begin{array}{l}\text { Constitution } \\
\text { NDPF }\end{array}$ & - & $\begin{array}{l}\text { Vision } 2030 \\
\text { MTP2 }\end{array}$ & 过 & $\begin{array}{l}\text { Constitution } \\
\text { Employment and } \\
\text { Labour Relations } \\
\text { Act }\end{array}$ & 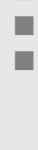 & $\begin{array}{l}\text { Constitution } \\
\text { NDPII }\end{array}$ & $\begin{array}{l}\text { Transport legislation setting } \\
\text { up statutory bodies }\end{array}$ \\
\hline $\begin{array}{l}\text { Collect sex- and gender-disaggregated transport data to inform } \\
\text { policy, plans and projects }\end{array}$ & ш & NDPF & a & $\begin{array}{l}\text { MTP2 } \\
\text { Performance Contract }\end{array}$ & - & FYDP ॥ & घ & PFMA & $\begin{array}{l}\text { Roads sub-sector } \\
\text { institutions }\end{array}$ \\
\hline
\end{tabular}




\begin{tabular}{|c|c|c|c|c|c|c|c|c|c|}
\hline \multirow{3}{*}{$\begin{array}{l}\text { Policy directive } \\
\text { Gender-equality-enhancing measures in the workplace } \\
\text { Non-discrimination against women }\end{array}$} & \multicolumn{8}{|c|}{ Legislation/policy/instrument } & \multirow{2}{*}{$\begin{array}{l}\text { Targeted sector } \\
\text { instrument }\end{array}$} \\
\hline & \multicolumn{2}{|c|}{ Ghana } & \multicolumn{2}{|c|}{ Kenya } & \multicolumn{2}{|c|}{ Tanzania } & \multicolumn{2}{|c|}{ Uganda } & \\
\hline & घ & Constitution & a & Employment Act & - & & - & & Roads sub-sector \\
\hline Non-discrimination against women & & $\begin{array}{l}\text { Constitution } \\
\text { National } \\
\text { Labour Act }\end{array}$ & घ & Constitution & a & $\begin{array}{l}\text { Constitution } \\
\text { Employment Act } \\
\text { Vision } 2025\end{array}$ & 口 & Constitution & $\begin{array}{l}\text { institutions } \\
\text { Technical specifications } \\
\text { for roads and bridges }\end{array}$ \\
\hline Equal employment opportunities for women and men & $\square$ & $\begin{array}{l}\text { Constitution } \\
\text { National } \\
\text { Labour Act }\end{array}$ & $\mathbf{\square}$ & Employment Act & घ & $\begin{array}{l}\text { Constitution } \\
\text { Employment Act }\end{array}$ & ㅁ & $\begin{array}{l}\text { Constitution } \\
\text { NDPI } \\
\text { Employment } \\
\text { Act }\end{array}$ & $\begin{array}{l}\text { Contract documents } \\
\text { (consultants and } \\
\text { contractors) }\end{array}$ \\
\hline $\begin{array}{l}\text { Affirmative action for women in infrastructure works/road } \\
\text { projects }\end{array}$ & - & & 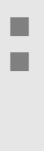 & $\begin{array}{l}\text { Vision } 2030 \\
\text { MTP2 }\end{array}$ & $\mathbf{\square}$ & FYDP ॥ & 口 & $\begin{array}{l}\text { Constitution } \\
\mathrm{NDPl} \\
\text { Employment } \\
\text { Act }\end{array}$ & \\
\hline Affirmative action for women in recruitment and training & & $\begin{array}{l}\text { Constitution } \\
\text { NDPF }\end{array}$ & a & $\begin{array}{l}\text { Constitution } \\
\text { Employment Act }\end{array}$ & घ & FYDP ॥ & - & & \\
\hline Gender awareness creation and capacity building & $\mathbf{\square}$ & NDPF & $\mathbf{\square}$ & Performance Contract & - & & घ & NDPII & \\
\hline Collect gender-disaggregated employment and training data & $\mathbf{\square}$ & NDPF & - & Employment Act & घ & FYDP ॥ & & & \\
\hline Flexible working conditions for women & घ & National & - & & - & & घ & Vision 2040 & \\
\hline $\begin{array}{l}\text { Provide separate latrine/toilet/bathroom facilities for female and } \\
\text { male employees }\end{array}$ & & $\begin{array}{l}\text { Labour } \\
\text { Act }\end{array}$ & $\mathbf{\square}$ & Employment Act & - & & & & \\
\hline Equal opportunities for female- and male-led contracting firms & & $\begin{array}{l}\text { Constitution } \\
\text { NDPF }\end{array}$ & $\mathbf{\square}$ & Constitution & घ & FYDP ॥ & ㅁ & $\begin{array}{l}\text { Constitution } \\
\text { NDPI }\end{array}$ & \\
\hline Fully paid maternity leave and job security & & $\begin{array}{l}\text { Constitution } \\
\text { National } \\
\text { Labour Act }\end{array}$ & $\mathbf{\square}$ & Employment Act & च & Employment Act & घ & $\begin{array}{l}\text { Employment } \\
\text { Act }\end{array}$ & \\
\hline
\end{tabular}

NDPF, National Development Policy Framework (Ghana); NGP, National Gender Policy (Ghana); MTP2, Second Medium Term Plan (RoK, 2013); NDPI, First National Development Plan (Uganda); NDPII, Second Nationa Development Plan (Uganda); PFMA, Public Finance Management Act (Uganda); FYDP II, Second Five Year Development Plan (URT, 2016) 
Table 3. Some key gender equality indicators by case study country (OECD, 2014; UNDP, 2016; WEF, 2017; World Bank, 2016)

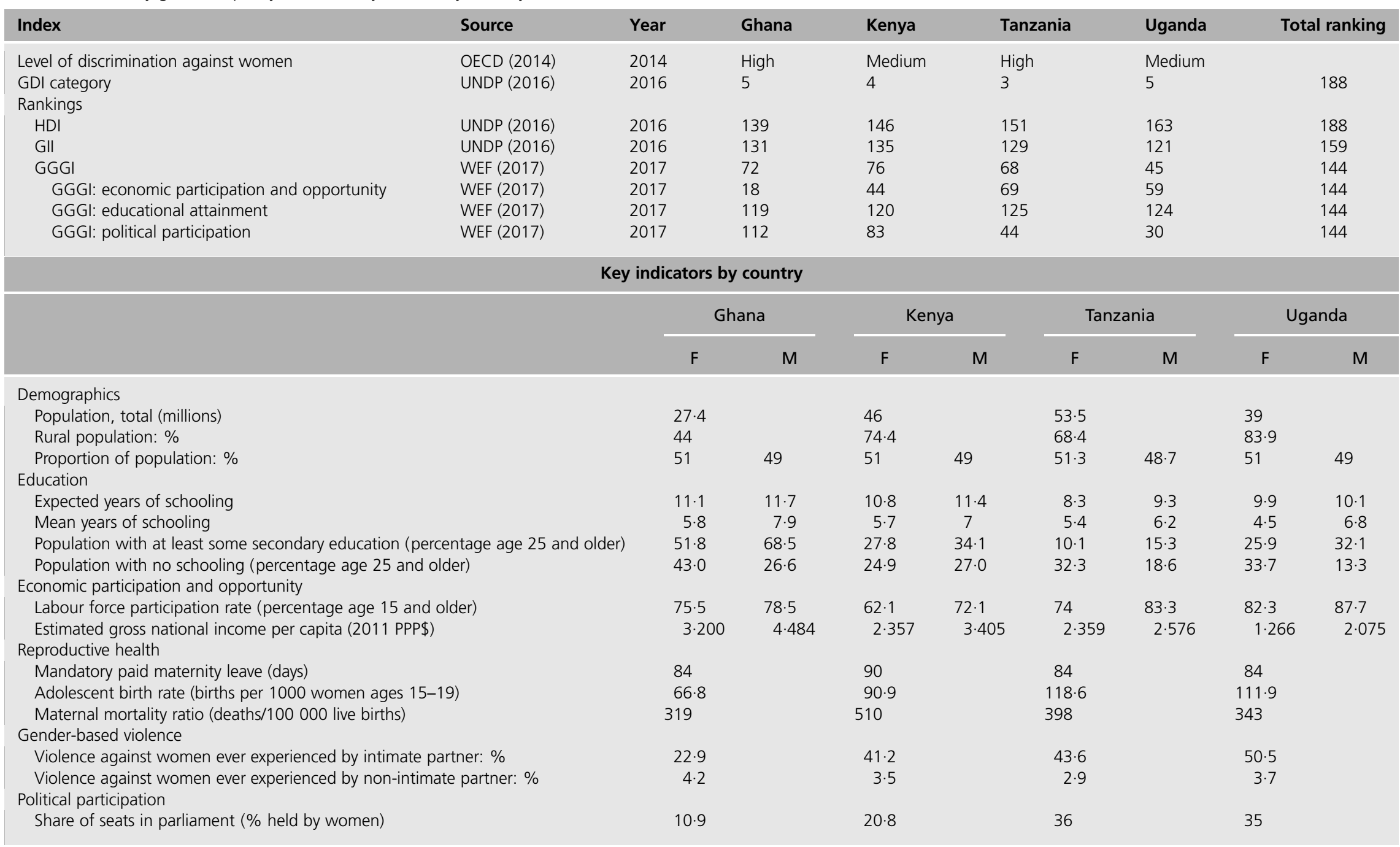

F, Female; GDI, gender development index; GGGI, global gender gap index; GIl, gender inequality index; HDI, human development index; M, Male; PPP\$, purchasing power parity in US\$ 
women's educational attainment relative to men's. As regards women's political participation, Uganda ranks 30, closely followed by Tanzania at 44 . In contrast, Kenya and Ghana rank poorly at 83 and 112, respectively. This is attributed to relatively low proportions of seats held by women in the respective national parliaments.

\subsection{Women's and men's work in the market economy} Women constitute a significant proportion of workers in agriculture, the largest and most important sector of African economies. For instance, in Ghana most rural women $(67 \cdot 9 \%)$ and men $(74.5 \%)$ are employed in the sector (GSS, 2014). In contrast, in Uganda, $69 \%$ of women compared with only $10 \%$ of men are employed in agriculture (UBOS, 2014). Anecdotal evidence suggests that an estimated $70 \%$ of agricultural produce is carried by head-loading - a task predominantly undertaken by women and their children (Porter et al., 2013; Tanzarn, 2013). In Kenya, women constitute $80 \%$ of agricultural workers, are responsible for most of the food storage and the transport of produce from farm to home $(80 \%)$ and undertake $60 \%$ of the harvesting and marketing of crops (AfDB, 2007). In Tanzania, women comprise more than half (54\%) of the agricultural labour force. Furthermore, $81 \%$ of women compared with $73 \%$ of men in employment are engaged in agriculture (FAO, 2010).

In Tanzania, other than head-loading/back-loading, women are nearly absent from other forms of agricultural transport such as operating bicycles, motorcycles, pick-ups and lorries (Njenga et al., 2015). In Uganda, women are, for the most part, not involved in agricultural marketing (MAAIF, 2010) beyond the first point of commercial interface.

Most of women's and men's trips to and from their fields and the markets are predominantly undertaken on community access roads or footpaths.

\subsection{Women and the care economy}

In addition to productive work, women take on a disproportionate responsibility of the labour- and time-intensive activities in the unpaid care economy. These involve work undertaken for the maintenance of the household and its members, such as caring for children, the sick and the elderly, as well as head- and back-loading heavy loads of water, firewood and food.

In Ghana, $68 \%$ of rural households use fuel wood for cooking, most of which $(92.4 \%)$ is collected predominantly $(71.6 \%)$ by adult women. Further to that, about five times the proportion of adult women $(60 \%)$ compared with adult men $(11 \cdot 6 \%)$ fetch water for their households (GSS, 2012).

In Tanzania women participate more in providing unpaid domestic services (87\%) than men (47\%) (NBS, 2017). Likewise, women in Uganda bear a disproportionate burden of domestic work $(74 \%)$ in general, fuel wood collection $(70 \%)$ and fetching water for domestic consumption (63\%) (UBOS, 2014). In Kenya, women are responsible for collecting drinking water in $57 \%$ of rural households (KNBS, 2014).

Women and girls typically make more than one trip per day to fetch water, frequently travelling long distances. Nearly half of the households in Tanzania (44\%) and Uganda (47\%) have to make a 30 min round-trip or longer for their water, compared with $15 \cdot 1 \%$ and $27 \cdot 8 \%$ in Ghana and Kenya, respectively (World Bank, 2016). In Kenya, 19\% of rural households spend more than $1 \mathrm{~h}$ per day fetching drinking water (CRS, 2010).

\subsection{Gender and access to skills relevant to transport}

Whereas gender parity in primary education has nearly been achieved in most of the case study countries, inequalities still persist. Table 4 shows the mean number of schooling years between men and women. Across all the case study countries, women have fewer average years of schooling than men. Illiteracy implies that women experience restricted access to work opportunities that require the ability to read and write.

Women are also under-represented in science-based courses in universities. For instance, in Ghana, the female share of graduates in engineering, manufacturing and construction is only 9\% (World Bank, 2016). In Uganda, women constituted 17.6\% and $11.4 \%$ of civil engineering and mechanical engineering graduates in 2012, respectively (Tanzarn, 2013).

Evidence from Ghana indicates that a negligible $0 \cdot 1 \%$ of females compared with $19 \cdot 4 \%$ of males aged 11 years and above had apprenticeship training in transport and material moving trades (GSS, 2014). One barrier to women's participation in the rural transport sector labour force could be the long hours usually expended by workers. More than half of the workers in the transport and storage sector work for $60 \mathrm{~h}$ or more per week. In contrast, $60 \cdot 7 \%$ of employees in agriculture, forestry and fishing work less than $40 \mathrm{~h}$ per week (MoGCSP, 2015).

Women constitute only $8 \%$ of the engineering workforce in Kenya. Additionally, the majority of the actors in transport operations, including owners, operators and traffic code enforcers, are men. Women comprise $13.6 \%$ of the informal

Table 4. Mean number of schooling years by case study country (World Bank, 2016)

\begin{tabular}{|c|c|c|c|c|c|c|c|}
\hline \multicolumn{8}{|c|}{ Mean number of schooling years } \\
\hline \multicolumn{2}{|c|}{ Ghana } & \multicolumn{2}{|c|}{ Kenya } & \multicolumn{2}{|c|}{ Tanzania } & \multicolumn{2}{|c|}{ Uganda } \\
\hline $\mathrm{F}$ & M & $\mathrm{F}$ & M & $\mathrm{F}$ & M & $\mathrm{F}$ & M \\
\hline $5 \cdot 8$ & $7 \cdot 9$ & $5 \cdot 7$ & 7 & 5.4 & $6 \cdot 2$ & 4.5 & 6.8 \\
\hline
\end{tabular}


transport owners and an even lower 5\% of transport service employees, the majority $(62 \cdot 3 \%)$ of whom are employed as conductors, office and route managers (Mwangi, 2014). In Tanzania, only $0 \cdot 2 \%$ of employed women are involved in transportation and storage (compared with $5 \%$ of men) and an even lower proportion $(0 \cdot 1 \%)$ in construction (compared with $4 \%$ of men) (NBS, 2014).

None of the civil engineering consulting firms in Uganda is owned by a woman and mainstream works/technical services departments are male dominated, with no female district engineers. Further to that, women generally constitute only $15 \%$ of those employed in works and transport sector public institutions in Uganda (Tanzarn, 2013).

Table 5 presents some key indicators regarding the distribution of economic opportunities between men and women in the case study countries.

\section{Gender mainstreaming in practice: case study programmes}

This section presents a summary of the gender performance of the case study programmes with a focus on the specific stages of the project cycle framework.

\subsection{Project identification}

All the projects had carried out baseline studies that included gender issues that were considered pertinent.

The VTTP programme in Tanzania was designed on the basis of extensive baseline data collected through the Makete Integrated Rural Transport Programme (MIRTP). The MIRTP baseline studies were pioneers in articulating the transport burden borne by women and girls in rural Africa. It demonstrated the daily transport drudgery experienced by women in meeting the basic needs of water, fuel and food-processing activities (Barwell and Malmberg Calvo, 1986, 1989). The studies showed that women accounted for nearly $67 \%$ of the household time spent on transport and $85 \%$ of the load carried, while men accounted for only $21 \%$ of the time and $11 \%$ of the load carried. Children accounted for the balance of time and load. A typical adult female undertook more than three journeys, spending over $4 \mathrm{~h}$ per day solely on transport, while men made just one journey, devoting fewer than $2 \mathrm{~h}$ per day on transport. Women in the Makete district typically moved about $50 \mathrm{~kg}$ each per day or $18 \mathrm{t}$ per year over a distance of about $4 \mathrm{~km}$.

In Ghana the TRPII baseline surveys identified head-porterage as a massive burden for women in the project communities. Further to that, they established that poverty rather than culture was the potential barrier to women's use of bicycles in the project communities. The project also identified women's time use relative to men's as an indicator of gender inequality. Two non-governmental organisations were identified to serve as a liaison between the project and the female beneficiaries.

Under Roads 2000 (Kenya), baseline studies were conducted to establish the level of women's engagement in business activities that could potentially be impacted by the project.

In Uganda, RSPS1, RSPS2 and RRP recognised the need for the utilisation of women-specific channels to disseminate employment and training opportunities and recommended the use of non-state gender justice organisations for the purpose. RSPS1 underscored how the interplay of social norms, values and practices undermine women and privilege men.

\subsection{Project design and appraisal}

The respective project formulation documents were reviewed to assess the extent to which these were responsive to the gender issues identified and to determine the strategies put in place

Table 5. Indicators of economic opportunities by case study country (World Bank, 2016)

\begin{tabular}{|c|c|c|c|c|c|c|c|c|c|}
\hline \multirow[b]{2}{*}{ Indicator } & \multirow[b]{2}{*}{ Year } & \multicolumn{2}{|c|}{ Ghana } & \multicolumn{2}{|c|}{ Kenya } & \multicolumn{2}{|c|}{ Tanzania } & \multicolumn{2}{|c|}{ Uganda } \\
\hline & & $\mathrm{F}$ & M & $\mathrm{F}$ & M & $\mathrm{F}$ & M & $\mathrm{F}$ & M \\
\hline Population with no schooling (age 25 and older 25): \% & 2012 & $43 \cdot 0$ & $26 \cdot 6$ & $24 \cdot 9$ & $27 \cdot 0$ & $32 \cdot 3$ & $18 \cdot 6$ & $33 \cdot 7$ & $13 \cdot 3$ \\
\hline $\begin{array}{l}\text { Female share of graduates in engineering, manufacturing and } \\
\text { construction: \% }\end{array}$ & 2014 & $9 \cdot 7$ & & - & & - & & - & \\
\hline Female share of graduates in science: \% & 2014 & $30 \cdot 3$ & & - & & - & & - & \\
\hline Proportion that do not own land (percentage female/male, age 15-49) & 2014 & $78 \cdot 1$ & & $61 \cdot 3$ & & - & - & $61 \cdot 3$ & \\
\hline Wage and salaried workers (percentage of female/male employment) & 2013 & $11 \cdot 4$ & $25 \cdot 3$ & - & - & $10 \cdot 7$ & $21 \cdot 4$ & $13 \cdot 4$ & $26 \cdot 1$ \\
\hline $\begin{array}{l}\text { Share of women in waged employment in the non-agricultural sector } \\
\text { (percentage of total non-agricultural employment) }\end{array}$ & 2013 & $31 \cdot 9$ & & $35 \cdot 7$ & & $32 \cdot 5$ & & $34 \cdot 7$ & \\
\hline Percentage of firms with female participation in ownership & 2013 & $31 \cdot 6$ & & $48 \cdot 7$ & & $24 \cdot 7$ & & $26 \cdot 6$ & \\
\hline Vulnerable employment & 2013 & - & - & - & - & $79 \cdot 7$ & $68 \cdot 5$ & $85 \cdot 5$ & $72 \cdot 1$ \\
\hline Account at a financial institution (age 15+): \% & 2014 & $34 \cdot 0$ & $35 \cdot 3$ & $51 \cdot 9$ & $58 \cdot 9$ & $17 \cdot 1$ & $21 \cdot 1$ & $23 \cdot 1$ & $32 \cdot 5$ \\
\hline Borrowed any money in the past year (age 15+): \% & 2014 & $35 \cdot 1$ & $37 \cdot 8$ & $78 \cdot 3$ & $80 \cdot 2$ & $54 \cdot 7$ & $56 \cdot 4$ & 75 & 83 \\
\hline Borrowed to start, operate or expand a farm or business (age $15+$ ): \% & 2014 & $9 \cdot 3$ & $11 \cdot 1$ & $21 \cdot 1$ & $27 \cdot 8$ & $18 \cdot 1$ & $26 \cdot 6$ & $21 \cdot 2$ & $23 \cdot 4$ \\
\hline
\end{tabular}


to address the potential barriers to women's equitable participation, relative to men's.

In Tanzania, the VTTP interventions explored the possibilities of transferring some of women's transportation responsibilities to men through the use of intermediate means of transport (IMTs). The LGTP project, which is a replication of some aspects of the VTTP, provides for the promotion of IMTs as cost-effective local transport. The LGTP also explicitly states that the programme would ensure that women would be given a voice in decision-making processes. In Ghana, the TRPII strategies enabled the introduction of low-cost IMTs, including bicycles and trailers, aimed at reducing head-porterage and thus alleviating women's transport burden.

In Uganda, the RSPS1 piloted a community transport and travel programme designed to generate lessons for promoting IMTs and for improving local transport infrastructure. It also emphasised the importance of involving women, as road users, in the transport improvement agenda. Further to that, it required road prioritisation procedures to solicit and incorporate women's views. RSPS 2 included a community access component with various measures to promote women's employment by defining minimum quotas for women's participation.

Roads 2000 in Kenya included community gender sensitisation as an integral part of project activities.

\subsection{Implementation and gender performance monitoring}

A variety of gender monitoring instruments were deployed in the four projects. The TRPII in Ghana included the performance monitoring indicators of

- the number of women employed in the project and their incomes

- the number of women engaged in income-generating activities arising out of the programme

- changes in the incidence of head-porterage

- the number and range of community self-help activities.

Tanzania's VTTP monitoring and evaluation framework included indicators for impacts of the transport interventions on the transport burden of women in terms of time and effort. The terms of reference for the VTTP periodic reviews specified that the consultant team would apply, among others, participatory procedures and flexible methods of capturing gender-disaggregated data. The LGTP formulation document specified that there would be a gradual introduction of (gender-sensitive) implementation targets to give time to test and perfect the procedures. The programme had provisions for indicators to be embedded in contracts to oblige contractors to record employment created for women and men.
The socio-economic baseline studies for Kenya's Roads 2000 programme captured data on women's employment in the projects and their level of engagement in business enterprises that developed along the roads that were to be improved.

\section{The RSPS1, RSPS2 and RRP in Uganda provided for}

the revision of social and gender baseline and performance monitoring indicators for roadworks

- the revision of formats and modalities for reporting on gender in the road sector

monitoring tender documents and contractor gender compliance

- the collection of gender-disaggregated roadworks data

- the establishment of a road sector social and gender information system and database

- costed and time-bound gender management and action plans with verifiable indicators to guide the systematic mainstreaming of gender in the respective project components

- flexible quotas for women's participation that could be realistically attained

- an assessment of the extent to which progress had been achieved in fulfilling the gender objectives of the respective projects and recommendations for changes needed, as appropriate.

All the projects had an aspect of institutionalising gender either through capacity building, engendering policy or training material. Despite the above, all the projects have a weakness in terms of gender reporting, knowledge sharing and in gender and transport policy advocacy.

\subsection{Gender budgeting}

One of the key challenges in the achievement of desired gender results arises out of inadequate allocation of resources for the implementation of the stated gender outcomes. The case studies from Ghana, Kenya and Uganda indicated that good attempts at ensuring budgetary provisions for gender had been made. TRPII in Ghana allocated US\$2.98 million $(3 \cdot 1 \%)$ of the total project sum of US\$96 million to activities designed to achieve gendered outcomes. Both phases of Roads 2000 in Kenya allocated a dedicated budget for mainstreaming cross-cutting issues, including gender. Uganda's RSPS1 recommended a dedicated budget line of about $5 \%$ to facilitate gender-oriented activities for all future Danida-funded road projects. In Tanzania, although the budget guidelines for the fiscal year 2016/2017 require all government agencies to integrate gender considerations in their budgets, there is no explicit gender budgeting in the LGTP programme.

\subsection{Evaluation and gender outcomes}

\subsubsection{Women's participation}

The projects achieved varying levels of women's participation. Under TRPII in Ghana, women constituted an average of 50\% 
of the labourers, which could be attributed to the ambitious target set $(70 \%)$.

Women's participation in both LGTP and VTTP activities in Tanzania was around $50 \%$. Women comprised $25 \%$ of the total person days generated in phase 1 of the Roads 2000 project in Kenya, which was lower than the defined target of $30 \%$. This increased to $35 \%$ during the second phase as a result of changes made to ensure women-friendly work sites - that is, the provision of mobile toilets and facilities for breast feeding.

The highest percentage achieved as regards women's participation in the trunk road rehabilitation component of Uganda's RSPS1 was $17 \cdot 1 \%$. This was quite impressive considering that the project employed equipment-based approaches to roadworks. Women's labour in contracted works of the district roads component of the RSPS1 constituted $23 \%$ of the total 485000 worker days. Under RSPS2 and RRP, about 30\% of labour-based worker-days were undertaken by women.

\subsubsection{Contribution to the alleviation of women's transport burden}

Whereas the bicycle-trailers and single-wheel farm vehicles introduced under TRPII in Ghana were considered unaffordable by many households, some women used their earnings from the project to purchase the former, thus potentially contributing to the reduction of the prevalence of head-porterage. Women were major beneficiaries of the auxiliary works of the trunk road rehabilitation component of Uganda's RSPS1. These included improvements in health facilities, water supplies, market structures, school facilities and the rehabilitation of several community access roads. In Tanzania, both the VTTP and the LGTP place strong emphasis on the promotion of IMTs and investments in non-transport interventions that would reduce the transport burden of women. The Roads 2000 programme in Kenya, however, does not explicitly address itself to the alleviation of women's transport burden, with gender interventions mainly focusing on employment creation.

\subsubsection{Promoting women's entrepreneurship in the construction industry}

One of the three sub-contractors under the equipment-based trunk road rehabilitation component of RSPS1 in Uganda was a woman. Under the RSPS1 district roads component, women constituted $11 \%$ of the total person training days in labourbased methods (LBMs). Further to that, one $(5 \%)$ of the 20 private-sector firms trained and eligible for certification as LBM contractors (rehabilitation) was owned by women. Furthermore, females comprised 106 of the 514 firms/ individuals (20.6\%) prequalified and trained by the Mt Elgon Labour-Based Training Centre (MELTC) to undertake labourbased routine maintenance. Women comprised about $15 \%$ and $2.5 \%$ of the trained contractor staff under RSPS 2 and RRP, respectively.

\section{Lessons learnt}

The lessons learnt were based on discussions with key informants and an analysis of available project reports, especially with regard to monitoring and evaluation systems.

- The first lesson learnt is the need to adopt a systematic approach to mainstreaming gender along all stages of the project cycle based on a comprehensive (and mandatory) gender analysis. This process should be underlined by sound gender-disaggregated baseline information aimed at understanding the pertinent gender issues and inequalities in the specific contexts. The baseline studies should help identify the specific gender issues that the interventions should address. All the programmes that were reviewed made a good attempt in identifying some specific gender objectives in their baseline studies. For example, Roads 2000 in Kenya and RSPS1, RSPS2 and RRP in Uganda focused their gender interventions on employment and enterprise development, while VTTP in Tanzania and TRPII in Ghana had a strong focus on promotion of non-motorised transport.

- Secondly, the significance of monitoring, evaluation, documenting and sharing lessons on what has worked and what has not worked cannot be over-emphasised. It was observed, for example, that whereas there is anecdotal evidence of good gender mainstreaming practices in Tanzania's VTTP, most were not documented. Similarly, the wide range of gender mainstreaming activities in Tanzania's LGTP have not been captured and disseminated due to a lack of routine monitoring and evaluation. In all the projects, it was observed that project managers, confronted with tight timeframes and budgets, prioritise reporting on procedural issues such as the project's physical outputs, procurement and financial management rather than on the more analytical issues of outcomes and impacts.

- Thirdly, one of the underlying reasons for the low visibility of gender mainstreaming activities is a lack of knowledge on how to set clear and integrated gender objectives, measurable indicators accompanied by building of the requisite capacity to monitor gender outcomes and impacts.

- Finally, participatory methodologies involving all stakeholders are important in building a common understanding of what the gender issues are, what objectives and targets should be set and how accountability should be enforced.

\section{Conclusions}

Women and men have distinct mobility patterns, accessibility priorities and concerns. There is recognition in policy and practice that there can never be sustainable development if half of the population is excluded from the processes and outcomes of investment programmes. While transport is a key enabler to the achievement of a significant number of sustainable 
development goals in developing countries (poverty, health, education, clean water, energy etc.), its role in this context has rarely been acknowledged, much less the way it can catalyse the achievement of these targets by embracing gender integration.

The case study countries have made good advances in enshrining gender equality within national laws and various development plans' policy plans including transport. The four transport programmes that are the subject of this research show there is progress in actualising national gender integration aspirations into the transport sector itself. Without exception, all the projects had mainstreamed gender into all the stages of the project cycle. However, it is notable that all the case study programmes were financed through donor funding, and gender mainstreaming was mandatory. It would be of interest to carry out comparative work between donorfunded and government-funded programmes to ascertain if gender mainstreaming in transport has been institutionalised fully through enabling mechanisms such as budgeting and the deployment of technical capacities for planning, implementation, monitoring and evaluation, reporting and dissemination functions. This would help re-examine the observation that gender mainstreaming efforts in transport are primarily donordriven (Porter, 2012; Starkey, 2001; Tanzarn, 2016).

\section{REFERENCES}

AfDB (African Development Bank) (2007) Kenya Country Gender Profile. AfDB, Abidjan, Côte d'Ivoire.

Barwell I and Malmberg Calvo C (1986) Makete Integrated Rural Transport Project, Preliminary Findings from Village Survey ILO. International Labour Organization, Geneva, Switzerland.

Barwell I and Malmberg Calvo C (1989) Makete Integrated Rural Transport Project. The Transport Demands of Rural Households: Findings from A Village Level Travel Survey. International Labour Organization, Geneva, Switzerland, paper 19.

Bryceson DF and Howe J (1993) Rural household transport in Africa: reducing the burden on women. World Development 21(11): 1715-1728.

Cresswell T and Uteng TP (2008) Gendered mobilities: towards an holistic understanding. In Gendered Mobilities (Uteng TP and Cresswell T (eds)). Ashgate, Aldershot, UK, pp. 1-12.

CRS (Catholic Relief Service) (2010) Gender and Diversity Situational Analysis, Kenya. CRS, Kenya Country Office, Nairobi, Kenya.

Curtis V (1986) Women and the Transport of Water. Intermediate Technology Publications, London, UK.

Dawson J and Barwell I (1993) 'Roads Are Not Enough'. New Perspectives on Rural Transport Planning in Developing Countries. Intermediate Technology Publications, London, UK.

Doran J (1990) A Moving Issue for Women: Is Low Cost Transport an Appropriate Intervention to Alleviate Women's Burden in Sub-Saharan Africa. School of Development Studies, University of East Anglia, Norwich, UK, Gender analysis discussion paper 1.

FAO (Food and Agriculture Organization of the UN) (2010) Gender Dimensions of Agriculture and Rural Employment: Differentiated Pathways Out of Poverty. FAO, Rome, Italy. See http://www.fao. org/docrep/013/i1638e/i1638e00.htm (accessed 17/07/2019).

GoU (Government of Uganda) (2005) Constitutional Amendment Act, 2005. GoU, Kampala, Uganda. See http://www.ulrc.go. ug/system/files force/ulrc resources/constitutional-ammendmentact-2005.pdf (accessed 17/07/2019).

GoU (2007) Uganda Vision 2040. GoU, Kampala, Uganda. See http:// npa.go.ug/wp-content/themes/npatheme/documents/vision2040.pdf (accessed 12/08/2019).

GSS (Ghana Statistical Service) (2012) Ghana Time use Survey 2009. How Ghanaian Women and Men Spend Their Time. GSS, Accra, Ghana. See http://catalog.ihsn.org/index.php/catalog/3779/ download/52413 (accessed 12/08/2019).

GSS (2014) Ghana Living Standards Survey Round 6: Labour Force Report. GSS, Accra, Ghana.

Howe J and Barwell I (1987) Study of Potential for IMT: Executive Summary and Main Report (Ghana). World Bank, Washington, DC, USA.

KNBS (Kenya National Bureau of Statistics) (2014) Kenya Demographic and Health Survey. KNBS, Nairobi, Kenya.

MAAIF (Ministry of Agriculture, Animal Industry \& Fisheries) (2010) Agriculture for Food and Income Security Agriculture Sector Development Strategy and Investment Plan: 2010/11-2014-15. MAAIF, Kampala, Uganda.

Malmberg Calvo C (1994) Case Studies on the Role of Women in Rural Transport; Access of Women to Domestic Facilities. World Bank, Washington, DC, USA, SSATP working paper.

MoGCSP (Ministry of Gender, Children and Social Protection) (2015) Ghana Gender Policy. MoGCSP, Accra, Ghana. See http://www. ghana.gov.gh/images/documents/national_gender_policy.pdf (accessed 12/08/2019).

Mudzamba E and ILO (International Labour Organization) (1998) The Transport Burden on Women and Girls in Zimbabwe's Rural Areas, vol. 2. ILO, Geneva, Switzerland.

Mwangi S (2014) Gender Relations in Public Road Transport in Africa. MA thesis, Institute of Diplomacy and International Studies, Nairobi, Kenya.

NBS (National Bureau of Statistics) (2014) Tanzania Integrated Labour Force Survey 2014. NBS, Dar es Salaam, Tanzania.

NBS (2017) Women and Men in Tanzania. Facts and Figures 2017. NBS, Dar es Salaam, Tanzania.

Njenga P (2016) Access in the rural context: challenges and special needs of developing countries. Expert Group Meeting on 'Special Needs and Challenges in Developing Countries for Achieving Sustainable Transport', New York, NY, USA. See https:// sustainabledevelopment.un.org/index.php?page =view \&type $=13 \&$ $\mathrm{nr}=1994 \&$ menu=23 (accessed 12/08/2019).

Njenga P and Tanzarn N (2018) Scaling Up Gender Mainstreaming in Rural Transport: Policies, Practices, Impacts and Monitoring Processes. International Forum for Rural Transport and Development, Pretoria, South Africa, Synthesis Report submitted to AfCAP.

Njenga P, Willilo S and Hine J (2015) First Mile Transport Challenges for Smallholder Tomato Farmers Along Ihimbo-Itimbo Road, Kilolo District Tanzania. ReCAP/Cardno, Thame, UK.

See http://research4cap.org/Library/Njenga-Willilo-Hine-IFRTD2015-FirstMileTransportTomatoesTanzania-Final-AFCAPTan2015c-v160114.pdf (accessed 17/07/2019).

OECD (Organisation for Economic Cooperation and Development) (2014) Gender, Institutions and Development Database. OECD, Paris, France. See http://stats.oecd.org (accessed 17/07/2019).

Porter G (2012) Transport Services and Their Impact on Poverty and Growth in Rural Sub-Saharan Africa: Literature Review. AfCAP, London, UK and Durham University, Durham, UK.

Porter G, Hampshire K, Dunn C et al. (2013) Health impacts of pedestrian head-loading: a review of the evidence with particular reference to women and children in sub-Saharan Africa. Social Science \& Medicine 88: 90-97. 
RoG (Republic of Ghana) (1992) Constitution of the Republic of Ghana. GoG, Accra, Ghana. See https://www.ghanaweb.com/ GhanaHomePage/republic/constitution.php (accessed 17/07/2019).

RoG (1995) Ghana Vision 2020 (The First Step 1996-2000) Presidential Report on Coordinated Programme of Economic and Social Development Policies. RoG, Accra, Ghana.

RoK (Republic of Kenya) (2007) Kenya Vision 2030. RoK, Nairobi, Kenya. See http://www.vision2030.go.ke/ (accessed $17 / 07 / 2019)$.

RoK (2010) The Constitution of Kenya, 2010. National Council for Law Reporting, Nairobi, Kenya. See https://www.wipo.int/edocs/ lexdocs/laws/en/ke/ke019en.pdf (accessed 12/08/2019).

RoK (2013) Second Medium-Term Plan, 2013-2017. RoK, Nairobi, Kenya. See http://sdgfunders.org/reports/secondmedium-term-plan-2013-2017-kenya-vision-2030/ (accessed 17/07/2019).

RoK (2015) The Public Procurement and Asset Disposal Act, 2015. RoK, Nairobi, Republic of Kenya. See http://ppoa.go. ke/images/downloads/Public $\% 20$ Procurement $\% 20$ and $\% 20$ Asset $\%$ 20Disposal\%20Act $\% 202015$.pdf (accessed 17/07/2019).

Starkey P (2001) Local Transport Solutions: People, Paradoxes and Progress. World Bank, Sub-Saharan Africa Transport Policy Program, Washington, DC, USA, SSATP Working Paper 56.

Tanzarn N (2013) Sub-Saharan Africa Transport Policy Program [SSATP] Support to the Implementation of the Government of Uganda's Gender Equality Policy Commitments in the Road Sector. SSATP, World Bank, Washington, DC, USA.

Tanzarn N (2016) Gender Issues Paper: Infrastructure Sector in Uganda. UN Entity for Gender Equality, New York, NY, USA.
Tanzarn N (2017) Scaling Up Gender Mainstreaming in Rural Transport: Policies, Practices, Impacts and Monitoring Processes. ReCAP, Thame, UK, Final Synthesis Report.

UBOS (Uganda Bureau of Statistics) (2014) Uganda National Household Survey 2012/2013. UBOS, Kampala, Uganda.

UNDP (United Nations Development Programme) (2016) Human Development Report 2016: Human Development for Everyone: The United Nations Development Programme 1 UN Plaza. UNDP. New York, NY, USA.

Urasa I (1990) Women and Rural Transport: An Assessment of Their Role in sub-Saharan Africa. International Labour Organization, Geneva, Switzerland.

URT (United Republic of Tanzania) (2000) The Tanzania Development Vision 2025. URT, Dar es Salaam, Tanzania. See http://www. tzonline.org/pdf/theTanzaniadevelopmentvision.pdf (accessed $17 / 07 / 2019)$.

URT (2004) The Constitution of the United Republic of Tanzania. URT, Dar es Salaam, Tanzania.

URT (2016) National Five Year Development Plan 2016/17-2020/21. URT, Dar es Salaam, Tanzania. See http://www.mof.go.tz/ mofdocs/msemaji/Five\%202016_17_2020_21.pdf (accessed $12 / 08 / 2019)$.

World Bank (2016) Gender Statistics. World Bank, Washington, DC, USA. See http://databank.worldbank.org/data/reports.aspx?Code= undefined\&id $=2 \mathrm{ddc} 971 \mathrm{~b} \&$ report_name $=$ Gender_Indicators_ Report\&populartype $=$ series (accessed 17/09/2019).

WEF (World Economic Forum) (2017) The Global Gender Gap Report 2016. WEF, Geneva, Switzerland. See http://www3.weforum. org/docs/WEF_GGGR_2017.pdf (accessed 17/07/2019). 